\title{
Editorial
}

\section{O SUS e o direito à saúde}

| Kenneth Rochel de Camargo Jr. |

Mais de vinte anos após a celebração de seu marco inaugural com o capítulo sobre saúde da Constituição Cidadã, talvez nos seja útil pensar o SUS não como um objeto com contornos definidos, mas como um conjunto de relações e sobretudo um processo.

Nesta lógica, os sucessivos embates em torno da efetiva implementação do conjunto de direitos previstos na Carta Magna não têm necessariamente um ponto de chegada fixo, uma vez que o que consideramos "direito à saúde" também se altera e expande ao longo do tempo. Da mesma forma, esses embates não são algo externo ao SUS, mas parte do mesmo, de sua história viva e em permanente construção.

O tema desta edição de Physis, organizado por Roseni Pinheiro e Felipe Asensi, apresenta vários momentos desta luta para que se exerça de fato o tão sonhado direito à saúde. Os artigos do tema são apresentados pelos seus organizadores, mais à frente.

$\mathrm{Na}$ seção de temas livres, temos uma ampla gama de objetos e abordagens, refletindo a dinâmica abrangente da produção intelectual do campo da Saúde Coletiva. Abrindo a seção, Berger e Ortega apresentam os embates de uma associação popular de Córdoba, Argentina, que ecoa muito da discussão do tema, ao tratar da luta dos moradores contra a aplicação de agrotóxicos em plantações vizinhas. Segue-se o artigo de Pereira, baseado em trabalho empírico com usuários do SUS no DF, Brasil, sobre suas estratégias para lidar com as incertezas relacionadas a seus problemas de saúde e as estratégias terapêuticas propostas para dar conta dos mesmos. Lins traz, por sua vez, tema similar, ao apresentar, também com base em estudo empírico realizado no Pará, Brasil, as representações sociais sobre a hanseníase de pessoas acometidas pela doença, seus familiares e os agentes de saúde envolvidos no seu acompanhamento. 
Rios, Parker e Terto Jr. nos trazem uma densa reflexão sobre as noções articuladas em torno da noção de "carne" no cristianismo, como subsídio para abordar as questôes da sexualidade no âmbito da Saúde Coletiva, com ênfase na perspectiva dos direitos sexuais e reprodutivos. Câmara, Cruz e Tambellini relatam os resultados de pesquisa sobre prevenção do uso de drogas em 23 municípios de quatro regiōes brasileiras, utilizando questionários. Suas conclusões retomam o conceito althusseriano de aparelho ideológico de Estado, analisando o papel dos mesmos como parte da dinâmica de prevenção do uso das drogas por parte dos jovens.

$\mathrm{O}$ artigo de Figueiredo et al. explora o processo de trabalho dos gestores municipais da Estratégia de Saúde da Família no Rio Grande do Sul, Brasil, com base em entrevistas semiestruturadas. Marques et al. analisam a relação entre as redes de suporte social e o aleitamento materno, com dados de estudo qualitativo realizado em um município de Minas Gerais, Brasil. Encerrando esta seção, Barbosa et al. apresentam os dados de estudo quantitativo que busca a correlação entre saúde bucal e qualidade de vida em crianças e adolescentes.

Inaugurando a seção de entrevistas, temos o diálogo de Spink com Nikolas Rose, relevante pesquisador do campo dos science studies na atualidade. Fechando este número, Rangel resenha The body multiple, de Annemarie Mol, interessante relato sobre um estudo empírico de como profissionais de saúde e pacientes produzem a objetividade daquilo que chamamos de "doença" através de seus múltiplos enactments.

Este é o primeiro número do vigésimo ano da Physis. Aproveitamos essa data para agradecer e homenagear Joel Birman, seu primeiro editor, e André Rios, que o sucedeu; seu trabalho incansável estabeleceu as bases para uma trajetória de sucesso. Tendo em vista a alta mortalidade de periódicos científicos, em particular no Brasil, este é um marco bastante relevante. Contando com financiamento restrito ao nosso publisher, o CEPESC, e à CAPES, via PROAP, manter a revista tem sido um desafio constante ao longo dessas duas décadas. Temos hoje no Brasil um conjunto expressivo de revistas de Saúde Coletiva, do qual nos orgulhamos em fazer parte, muitas das quais lutam com dificuldades semelhantes. Tendo em 
vista o volume de recursos destinado à pesquisa pelas agências de fomento - que

esperamos que cresça cada vez mais -, o investimento dessas mesmas agências na sustentação dos periódicos que vão divulgar os resultados das pesquisas é irrisório. A ampliação do financiamento para periódicos científicos é fundamental não apenas para a sobrevivência destes mas também para a própria ciência brasileira.

O ano de 2010 também marca os 40 anos da criação do Instituto de Medicina Social da Universidade do Estado do Rio de Janeiro. Physis, revista do IMS, se orgulha em ser parte dessa história. Pretendemos nos estender mais sobre este marco em ediçōes futuras.

A partir deste ano, todo o processo de gerenciamento de submissões da revista passa a ser feito exclusivamente online, no endereço http://submission.scielo.br/ index.php/physis (site mantido pela SciELO). Pedimos aos nossos colaboradores que leiam com atenção as novas normas de submissão; em particular no que se refere ao envio do manuscrito. Como as informaçôes referentes a autoria, bem como resumo e palavras-chave, têm campos específicos no formulário de entrada, o manuscrito não deve trazer nenhum destes elementos, e não deve ter nenhuma informação que possibilite a identificação de seus autores, uma vez que o arquivo será enviado aos pareceristas.

Lembramos ainda que nossa seção de cartas continua à espera de suas contribuições. 